Note

||||||||||||||||||||||||||||||||||||||||||

\title{
Possibility of Content Change in Bioethanol Gasoline during Pre-treatment Process for Using Accelerator Mass Spectroscopy
}

\author{
Masaaki SAIto, Shunji Yunoki and Takashi Suzuki \\ Tokyo Metropolitan Industrial Technology Research Institute \\ 2-11-1 Fukasawa, Setagaya-ku, Tokyo 158-0081, Japan
}

Received June 8, 2010

\begin{abstract}
We attempted to determine the bioethanol content of E3 gasoline by applying ASTM D6866 method B. In the pre-treatment process using accelerator mass spectroscopy (AMS), the graphite samples were prepared from E3 gasoline. Three portions of the same graphite sample were measured, and the contents agreed within the measurement error of AMS. The graphite samples prepared from eight portions of the same E3 gasoline sample were measured, but the accuracy was insufficient. There are many kinds of hydrocarbon compounds in the gasoline and their boiling points are different. The content of bioethanol was found to decrease with vaporization when E3 gasoline was placed in open air. A very small amount of E3 gasoline is pre-treated for AMS and the volatile loss cannot be ignored. It seems that the content change of bioethanol was caused by vaporization of E3 gasoline during the pre-treatment process.
\end{abstract}

Key Words : bioethanol, biogasoline, accelerator mass spectroscopy, ASTM D6866, liquid scintillation counting

\section{Introduction}

Recently, much attention has been paid for reducing $\mathrm{CO}_{2}$ emission to avoid further increases in global warming by greenhouse effects $^{1)-3)}$. Bioethanol gasoline, i.e., E-gasoline, has the potential to reduce the emission. Bioethanol is a fuel with biological origins, and its burning results in no net release of $\mathrm{CO}_{2}$ into the atmosphere. Therefore, its use is regarded as carbon neutral. However, bioethanol is currently more expensive than gasoline $e^{4)}$ and some countries have imposed lowered taxes on E-gasoline consumption to stimulate its use.

Bioethanol and synthetic ethanol are chemically identical and cannot be distinguished with each other using other measurements, such as chromatography or spectroscopy. Only radiocarbon analysis can be employed to identify the bioethanol content, based on the principle that ${ }^{14} \mathrm{C}$ exists in bioethanol but can be neglected in synthetic ethanol. American Society for Testing and Materials (ASTM) D6866 ${ }^{5)}$ has been developed to determine the biobased carbon contents in manufactured products by using ${ }^{14} \mathrm{C}$ measurements, e.g. accelerated mass spectrometry (AMS) and liquid scintillation counting (LSC).

We have developed a simple method to determine the bioethanol content in E-gasoline using a two-step extraction with water ${ }^{6), 7)}$. It was demonstrated that bioethanol content in Egasoline containing $3 \%$ or $10 \%$ bioethanol was determined by LSC measurements of the water phases. The LSC method does not require any chemical modification of E-gasoline.

Although ASTM D6866 is generally used for solid-state products ${ }^{8)}$, the ASTM method using 
AMS can also be applied to the determination of bioethanol content in E-gasoline ${ }^{9}$. This study describes the results of the determination of bioethanol content in E-gasoline using AMS according to the ASTM D6866 method B, in which the liquid samples were transferred to graphite. The results were compared to those of the LSC method, and the difference in accuracy between the two methods was discussed.

\section{Experiment}

\section{$2 \cdot 1$ Pre-treatment of E-gasoline}

Ethanol 99.5\% grade (Wako Pure Chemical Co., Japan) was used as bioethanol. The bioethanol and the fossil gasoline (a commercial gasoline supplied from a gas station in Tokyo) were blended at the weight ratio of $3: 97$ (E3 gasoline) and measured by AMS and LSC measurements.

\section{$2 \cdot 2$ AMS measurement}

Three private companies were commissioned separately to determine ${ }^{14} \mathrm{C}$ content in the same E3 gasoline sample. The companies, $\mathrm{A}, \mathrm{B}$, and $\mathrm{C}$, specialize in ${ }^{14} \mathrm{C}$ measurement by AMS. These companies prepared graphite samples independently from the same E3 gasoline sample according to method B of ASTM D6866 as described below.

E3 gasoline was oxidized by combustion in a quartz-glass tube or Pyrex tube together with copper (II) oxide. The $\mathrm{CO}_{2}$ generated was purified and deoxidized to graphite with Fe catalyst. The AMS measurements of the graphite samples were performed identically to the conventional carbon dating measurement. Graphite samples from fossil gasoline, bioethanol, and oxalic acid standard (OAS; a standard reference material) were also prepared. AMS measurement clarifies the quantity of ${ }^{14} \mathrm{C}$ relative to
${ }^{12} \mathrm{C}$. The carbon molar ratios of the graphite samples to OAS provided the percent modern carbon $^{8)}(\mathrm{pMC})$.

The pMC of bioethanol $\left(p M C_{b i o}\right)$, fossil gasoline $\left(p M C_{g a s}\right)$, and $\mathrm{E} 3$ gasoline $\left(p M C_{E 3}\right)$ were obtained. The biobased carbon content in E3 gasoline $\left(C_{E 3}\right)$ was obtained by the following equation :

$$
\begin{aligned}
C_{E 3}(\%)= & 100\left(p M C_{E 3}-p M C_{g a s}\right) / \\
& \left(p M C_{b i o}-p M C_{g a s}\right)
\end{aligned}
$$

The Bioethanol content (wt\%) in E3 gasoline was obtained by the following equation using mass $(W)$ of chemical components in E3 gasoline.

$$
\begin{gathered}
\text { Bioethanol content }(\mathrm{wt} \%)= \\
100 W_{\text {bio }} /\left(W_{\text {bio }}+W_{\text {gas }}\right)
\end{gathered}
$$

The relation between carbon content and the mass of chemical compound is as follows.

$$
C_{E 3}(\%)=100 W_{b i o} R_{b i o} /\left(W_{b i o} R_{b i o}+W_{g a s} R_{g a s}\right)
$$

Where $R_{b i o}(=0.52)$ is the carbon ratio in bioethanol, and $R_{g a s}(=0.84)$ is the carbon ratio in n-octane.

The following equation (4) was obtained from equations (1), (2) and (3), and was used as bioethanol content by AMS measurement.

$$
\begin{aligned}
& \text { Bioethanol content }(\mathrm{wt} \%)= \\
& 100 /\left\{\left[\left(p M C_{b i o}-p M C_{g a s}\right) /\right.\right. \\
& \left.\left.\quad\left(p M C_{E 3}-p M C_{g a s}\right)-1\right]\left(R_{b i o} / R_{g a s}\right)+1\right\}
\end{aligned}
$$

\section{$2 \cdot 3$ LSC measurement}

The bioethanol content in E3 gasoline was also determined by two-step extraction LSC measurement at Tokyo Metropolitan Industrial Technology Research Institute (TIRI) as 

pre-treatment process for using accelerator mass spectroscopy

reported previously ${ }^{6), 7)}$. Briefly, bioethanol in $100.0 \mathrm{~g}$ E3 gasoline was extracted with $3 \mathrm{~g}$ water. The water phases were mixed with a scintillator (Clear-sol II, Nacalai Tesque, Kyoto), and subjected to LSC using Tri-Carb $3180 \mathrm{TR} / \mathrm{SL}$ (PerkinElmer, USA) in the ${ }^{14} \mathrm{C}$ normal counting mode for $500 \mathrm{~min}$. Standard samples of bioethanol and a background sample (fossil-derived methanol) were also measured. The background count rate was $14-15 \mathrm{cpm}$. The disintegraTable 1 Percent modern carbon (pMC) measured by AMS commissioned by three companies.

The pMC for E3 (3.04 wt\%) gasoline was 1.6\% - 2.41 $\%$, and the standard deviation $(2 \sigma= \pm 0.55 \%)$ was much larger than the measurement error of AMS $(2 \sigma= \pm 0.10 \%)$

\begin{tabular}{lrcc}
\hline & \multicolumn{3}{c}{ pMC (\%) } \\
\cline { 2 - 4 } & Company A & Company B & Company C \\
\hline Gasoline & $0.14 \pm 0.02$ & & $0.19 \pm 0.05^{9)}$ \\
Bioethanol & $113.16 \pm 0.50$ & $112.1 \pm 0.4$ & $112.89 \pm 0.32$ \\
\hline E3 gasoline & $1.97 \pm 0.08$ & $1.6 \pm 0.1$ & $1.76 \pm 0.08$ \\
(3.04 wt \%) & $2.33 \pm 0.08$ & & $1.95 \pm 0.08$ \\
& $2.41 \pm 0.08$ & & $2.03 \pm 0.10$ \\
& & & $2.22 \pm 0.08$ \\
\hline
\end{tabular}
tions per minute (DPM) were used as the ${ }^{14} \mathrm{C}$ radioactivity to determine the bioethanol content.

\subsection{Vaporization loss of E3 gasoline}

To investigate the change of bioethanol content in E3 gasoline during vaporization, about $200 \mathrm{~g}$ of E3 gasoline were poured into a stainless steel tray $(200 \times 260 \times 50 \mathrm{~mm})$ and placed on an electronic balance in open air at room temperature. When the weight reached the value of $0 \%, 1.8 \%, 10 \%$, or $20 \%$ loss by vaporization, the E3 gasoline was sampled from the tray and the bioethanol contents were determined by the LSC measurement described above.

\section{Results}

Acceptable tolerance level of $\pm 5 \%$ (95\% confidence interval $2 \sigma$ ) is the standard in this report. Table 1 shows the results of AMS measurements for eight graphite samples prepared by three companies individually from the same E3 gasoline (3.04 wt\%) sample. The $\mathrm{pMC}$ in the eight graphite samples was more widely dispersed $(2 \sigma= \pm 0.55 \%)$ than the measurement errors of AMS, $2 \sigma= \pm 0.10 \%$.

Figure 1 shows the bioethanol content in E3 gasoline determined from the pMC shown in Table 1 using equation (4). The variation, $2 \sigma$ $= \pm 0.82 \%$, was much larger than the measurement error of AMS, $2 \sigma= \pm 0.13 \%$. The bioethanol content did not agree well with the prepared value $3.04 \%$; this unexpected discrepancy is examined below.

Three portions of the same graphite sample prepared from E3 gasoline were subjected to AMS measurements. The pMC obtained were $2.20 \pm 0.08 \%, 2.25 \pm 0.10 \%$, and $2.22 \pm 0.08 \%$. The variation of the pMC, $2 \sigma= \pm 0.06 \%$, was within the measurement errors of AMS, $2 \sigma= \pm 0.10 \%$, and is reasonable.

The bioethanol content of E3 gasoline was also determined by the LSC measurement. The results agreed with the prepared content as shown in Fig. 1. The standard deviation, $2 \sigma=$ $\pm 0.2 \%$, was lower than the LSC counting error, $2 \sigma= \pm 0.5 \%$, and is reasonable.

The relation between bioethanol content and E3 gasoline vaporization loss was examined by the LSC measurement. Fig. 2 shows the bioethanol content as a function of the E3 gasoline loss during vaporization. The bioethanol content decreased with vaporization of E3 gasoline in the range of weight loss $10 \%-20 \%$. 


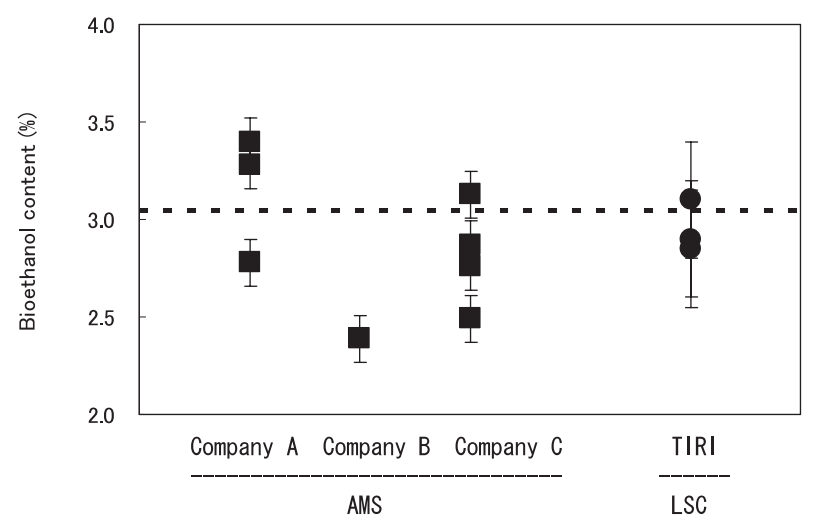

Fig. 1 Bioethanol content of the same E3 gasoline (3.04 wt\%) measured by AMS and LSC.

TIRI : Tokyo Metropolitan Industrial Technology Research Institute.

The variation of AMS with 95\% confidence interval $(2 \sigma= \pm 0.82 \%)$ was much larger than the measurement error $(2 \sigma= \pm 0.13 \%)$ of each error bar.

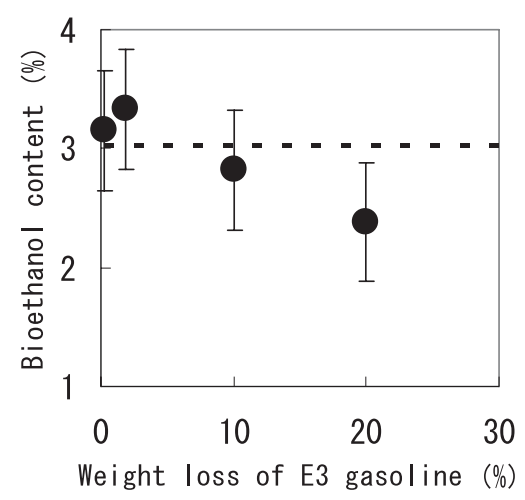

Fig. 2 Change of bioethanol content as a function of weight loss of E3 gasoline.

E3 gasoline was placed in open air at room temperature. The bioethanol content was determined by LSC, in which the error bar indicates counting error $= \pm 2 \sigma$.

The bioethanol content decreased with vaporization loss of E3 gasoline.

\section{Discussion}

AMS is an accurate method for ${ }^{14} \mathrm{C}$ determination in solid samples, as mentioned in the result of the same graphite sample. However, the content of graphite samples prepared from the same E3 gasoline did not agree well. It is suggested that the disagreement was caused by the graphite pre-treatment process.

We consider below the vaporization of E3 gasoline in the graphite pre-treatment process shown as below. Gasoline contains many kinds of hydrocarbons (boiling points : $30-200{ }^{\circ} \mathrm{C}$ ). Compounds with boiling points lower than ethanol (boiling point: $78{ }^{\circ} \mathrm{C}$ ) will be preferentially lost at the early stage of vaporization. And at the next stage, bioethanol will be preferentially lost and high boiling-point compounds will remain. Thus, the bioethanol content will increase during the earlier vaporization and decrease during the later vaporization.

This assumption is supported by our result that the bioethanol content decreased by vaporization when E3 gasoline was placed in open air. The changes in bioethanol content probably caused the error in AMS measurement.

The AMS measurement requires about 20 $\mathrm{mg}$ of sample, and the LSC measurement requires $100 \mathrm{~g}$ of sample. The surface-to-volume ratio of the E3 gasoline sample for the AMS measurement is 17 times larger than that for the LSC measurement. Thus, E3 gasoline tends to be influenced by vaporization loss in the AMS pre-treatment process.

In conclusion, we attempted to determine the bioethanol content in E3 gasoline by the ASTM D6866 method B. AMS was a very accurate method for the measurement of ${ }^{14} \mathrm{C}$ in solid samples. However, the bioethanol content did not agree well with the prepared content for E3 gasoline. Content change was probably caused by the vaporization of E3 gasoline dur- 

pre-treatment process for using accelerator mass spectroscopy

ing the sample pre-treatment process for AMS measurement.

This research was supported in part by a grant program "10-Year Project for a CarbonMinus Tokyo” from Tokyo Metropolis.

\section{References}

1) Bojic, M. and Mourdoukoutas, P., Energy saving does not yield $\mathrm{CO}_{2}$ emissions reductions: the case of waste fuel use in a steel mill, Appl. Therm. Eng., 20, 963-975(2000)

2) Chase, T. N., Pielke, R. A., Kittel, T. G. F., Zhao, M., Pitman, A. J., Running, S. W. and Nemani, R. R., The relative climatic effects of land cover change and elevated carbon dioxide combined with aerosols : a comparison of model results and observations, J. Geophys. Res., 106, 31685-31691 (2001)

3) Apak, R., Alternative solution to global warming arising from $\mathrm{CO}_{2}$ emissions-Partial neutralization of tropospheric $\mathrm{H}_{2} \mathrm{CO}_{3}$ with $\mathrm{NH}_{3}$, Environ.
Prog., 26, 355-359 (2007)

4) Demirbas, A., Progress and recent trends in biofuels, Prog. Energy. Comust. Sci., 33, 1-18 (2007)

5) ASTM D6866-08, Standard test methods for determining the biobased content of solid, liquid and gaseous sample using radiocarbon analysis, ASTM International, West Conshohocken, USA (2008)

6) Yunoki, S. and Saito, M., A simple method to determine bioethanol content in gasoline using two-step extraction and liquid scintillation counting, Bioresource Technol., 100, 6125-6128 (2009)

7) Saito, M. and Nakamura, M., Easy C-14 measurement of bio-gasoline E3 by double-extraction with water, RADIOISOTOPES, 56, 529-531 (2007)

8) Stuiver, M. and Polach, H. A., Discussion: Reporting of 14C data, Radiocarbon, 19, 355-363 (1977)

9) Standardization study of evaluation methods for biomass materials 20-R-4, p.113, The Mechanical Social Systems Foundation, Tokyo (2009)

\title{
要旨
}

\section{加速器質量分析法前処理工程におけるバイオエタノールガソリン組成変化の可能性}

\author{
斎藤正明，柚木俊二，鈴木隆司 \\ 地方独立行政法人 東京都立産業技術研究センター \\ 158-0081＼cjkstart東京都世田谷区深沢 2-11-1
}

\begin{abstract}
ASTM D6866 method B 法にしたがい，E3 ガソリン中のバイオエタノール濃度の定量を試みた。 加速器質量分析（AMS）の前処理として，E3 ガソリンからグラファイト試料を調製した。同一の グラファイト試料から小分けした 3 試料の定量結果は、AMS の測定誤差内に収まった。しかし， 同一の E3 ガソリンを 8 試料に小分けし，調製したグラファイト試料を測定したところ，十分な精 度が得られなかった。ガソリンには多種の炭化水素化合物が含まれており，それらの沸点は異なっ ている。E3 ガソリンを空気中に放置すると，そのバイオエタノール濃度は蒸発と共に低下するこ とが確認できた。AMS 測定法の試料調製では極めて微量の E3 ガソリンを取り扱い，揮発損失は 無視できない。E3 ガソリンの蒸発は試料調製時に濃度変化を引き起こしたと思われる。
\end{abstract}

